\title{
SEMANTIC AND STRUCTURAL PECULIARITIES OF TRANSLATING PHRASEOLOGICAL UNITS WITH MONEY COMPONENT (BASED ON MODERN ENGLISH AND GERMAN ECONOMIC TEXTS)
}

\section{Nadiia Sheverun ${ }^{1}$ \\ Halyna Lejzjus ${ }^{2}$}

DOI: https://doi.org/10.30525/978-9934-26-049-0-25

Abstract. The purpose of the paper is to summarise and present semantic and structural peculiarities of phraseological units with MONEY component translation, based on modern English and German Economic texts. Methodology. The survey is based on comparison of semantic and structural peculiarities of phraseological units with MONEY component, that can be used in modern Economic texts in English and German languages and main methods of their translation into the Ukrainian language. For research of features of phraseology units with a component on denotation of MONEY translation we analysed 164 English phraseological units with the structure of word-combinations, that were investigated and described the main ways of their translation and 103 phraseological units from the economic articles of German newspapers. The analysis of the economic articles gave possibility to carry out thematic classification of phraseological units with the component-name MONEY in English (money, penny, cent, dollar, pound, cash) and German languages (Geld, Mark, Euro, Cent), within the framework of that the groups of phraseological units are distinguished with sema composition of the meaning. According to semantic classification English and German phraseology units with a MONEY component were divided into such groups: on denotation of riches and profit, wastefulness and charges, feelings and looks of man, relation of man to money, poverty and lack of money and on denotation of currency and bank transactions.

\footnotetext{
${ }^{1}$ Candidate of Pedagogical Sciences,

Associate Professor at Department of Foreign Philology and Translation,

National Transport University, Ukraine

${ }^{2}$ Candidate of Philology Sciences,

Associate Professor at Department of Foreign Philology and Translation,

National Transport University, Ukraine
} 
The percentage ratio of semantic groups of English and German phraseological units with MONEY component in the economic sphere is represented on diagrams. Basic methods of phraseological units translation that are used by translators for the achievement of maximal adequacy of translation are distinguished. Among the methods of English phraseological units translation with a MONEY component the following one are distinguished: selection of equivalent, analogue, by the method of literal and descriptive translation whereas German phraseology units with a MONEY component are translated by phraseology and unphraseology methods; to phraseology the method of selection of eauivalent or analogue is taken, to unphraseology correspond calquing and descriptive translation. Carried analysis of features of English and German phraseology units with a MONEY component into the Ukrainian language translation did possible the reflection of research results by means of the diagram.

\section{Introduction}

Semantic ans structural nature of phraseology units is various and shows up in the features of elements of external form: structural organization, component composition, system of morphological categories and forms of analysed phraseology units. Momentous (verb, noun, adjective, pronoun) or unmomentous (prepositions, conjunctions, particles) parts of speech, that are distinguished as components of phraseological unit, keeping the formal separateness of word, stop to be the fact of autonomous nomination and lose grammatical properties of free word, converting the separate elements of the former meaning into the elements of integral phraseology meaning [7, p. 184-218].

The concept of MONEY is a fragment of the picture of the world and occupies one of the main positions in the system of national values. Money is an integral part of our lives and a necessary part of it. Attitudes towards money are changing against the background of transformations taking place in society. That is why an urgent problem for linguists is to study ways to denote this area by language, as well as to identify through these means the features of this conceptual area, because in the word and in its verbal definition the results of cognitive efforts of the human mind are recorded.

The concept of MONEY reflects a complex system not only of material and monetary relations, but also allows us to see the system of spiritual, moral and ethical values of human society as a whole, and the spiritual 
world of the individual. The linguistic picture of the world opposes the scientific picture to the extent that the lexical meaning of the word opposes the concept, the encyclopedic definition. At the same time, the very lexical meaning recorded in the dictionary is the meaning that people have in mind when using the word.

Component analysis of the concept notion shows that its content and scope reveal the following semas:

- form of existence (coins and banknotes);

- function (means of payment, a measure of value in the sale);

- amount.

The study of the conceptual sphere of «MONEY» is explained by the fact that this concept belongs to the value dominants, the totality of which is the views of a culture.

\section{Structural features of phraseology units with a component for the notation of money in economic texts units in English and German languages}

Whereas the aim of our research consists in the analysis of structural and semantic features of phraseology units with the structure of wordcombinations, then for basis grammatically-structural classification of V. D. Uzhchenko and D. V. Uzhchenko is taken, that distinguish the following digits of the phraseological units built after the model of word-combinations: noun, verbal, adverb and adjective [6, p. 104-109]. By the method of continuous selection from texts of the English-language newspapers «Financial Times» and «Wall Street Journal» it was selected 164 English phraseological units with the MONEY components «money, penny, cent, dollar, pound, cash» with the structure of word-combinations. Now consider phraseology units from the structural point of view in detail. Under verbal phraseology units understand phraseological units the cored word of that is a verb. Verbal phraseology turns can have one dependent word (for example: pay top dollar - платити шалені гроші, throw money at something - викидати гроші на щзось, bet one`s bottom dollar - поставити на все) or whole inferior word-combination (for example: money answers all things - $3 a$ все відповідають гроші, mоnеy makes a man free (recommends a man) everywhere - гроші роблять людину вільною де б вона не була, топеу never comes out of season - гроші ніколи не виходять з моди). 
Among verbal phraseological units distinguish:

a) V+ N, for example: make the топеу fly - жбурляти грошима, уои can whistle for your mопеу - плакали твої гроші, you can give your monеy up for lost-nлакали твої гроші;

b) V + Prep. + N, for example: be in the money (in pocket, in cash) - npu грошах, have a good run for your топеу-мати великий період успіху та насолоди, play for топеу - грати на гроші;

c) $\mathrm{V}+\mathrm{Adj}$. + N, for example: bring an amount of monеy in - заробляти, приваблювати громі; be good топеу - бути вигідним; bet your bottom dollar-коли ти впевнений, щзо хтось щзось зробить, чи щзось трапиться.

The analysis of actual material testifies that verbal models are the most numerous group of phraseology units with the structure of wordcombination (overall 63 phraseology units, id est $38 \%$ of selection).

Noun or substantive phraseological units are phraseology units that are functionally correlated with a noun. The structure of substantival phraseology units mostly represent a proof connection of the cored noun with an adjective or preposition, for example: monеy is nо object-cума не має значення; in for a penny, in for a pound - за будь-яку ціну.

Substantival phraseological units can be divided into such sub-groups:

a) $\mathrm{N}+\mathrm{N}$, for example: money is power - гроші - cила; monopoly топеу - гроші, які мають малу ијнність, або взагалі ї̈ не мають, тобто не катуються; sеed топеу - гроші, які використовуються, щуоб почати бізнес чи іншу справу (початковий капітал);

b) N's + N, for example: see the colour of someone's money - мamu доказ, щчо хтось може заплатити; put one's money on a scratched horse - прорахуватися;

c) $\mathrm{N}+$ prep $+\mathrm{N}$, for example: a run on the dollar/pound - коли багато людей продає долари і їх иінність падає; heaps (pots, piles) of топеу - великі гроші; топеу for jam, money for old rope - гроші, отримані задарма; ту топеу's оn somebody - ви думаєте, щчо хтось виграє змагання;

d) $\mathrm{N}+$ and $+\mathrm{N}$, for example: penny wise and pound foolish - звертай увагу на дрібниці, а не на основне; реппу аnd penny laid up will be тапу - пенні до пенні збирається - от і багато виходить;

е) A + N, for example: folding топеу - паперові банкноти; soft топеу паперові гроші, банкноти; hard топеу-металеві гроші, монети. 
As a result of undertaken study substantival phraseological units made 52 units, id est $32 \%$ of selection.

Adjective phraseology units are phraseological units the cored component of that is an adjective, for example: cold hard cash-готівка; smart mопеу - компенсація; spending топеу - готівка; dirty топеу підвищена зарплата робітників, які виконують неприйнятну, чорну роботу; red cent-мала сума грошей.

Adjective phraseological units made 39 units, id est $24 \%$ of selection.

Among the investigated phraseology units with a MONEY component adverbial phraseological units were also distinguished. Phraseological units that are functionally correlated with an adverb belong to adverbial. Adverbial phraseology units are presented by the following examples: almighty dollar - гроші - важливіші за будь-щз, taken топеу - грошові знаки, розмінна монета; not for all the money in the world - ні за які гроші.

The analysis of material shows that adverbial phraseology units with a MONEY component fold the least part (overall 10 phraseology units, id est $6 \%$ of selection).

And now consider a selection from the economic articles of German newspapers «Handelsblatt», «Wirtschaftswoche» in detail, where 103 phraseological units were educed with the MONEY components of Geld, Mark, Euro, Cent. All phraseological units with a MONEY component were investigated and classified according to structural and semantic classification of scientists A. M. Iskoz and A. F. Lenkova, that sufficiently and thoroughly presented classification of modern phraseology of German [4, p. 24]. It is known in domestic and foreign linguistics as traditional structural and semantic, according to which phraseological units of German are divided into the following groups: pair words, idioms, winged expressions and proverbs.

Stable word-combinations that consist of two words understand under pair words (Wortpaare). Exactly in German pair words are widespread and are characterized as phraseology connections. Pair combination of words are phraseological units with an integral meaning, that arises up as a result of semantic transformation of coordinating connections that include two homogeneous words and unite by means of conjunctions und, oder, weder... noch. As a connecting component of pair words conjunction und is used 
more often, for example: auf Heller und Pfennig Rechnung ablegen звітувати за кожну копійку; mit auf Heller und Pfennig abrechnen сповна розрахуватися.

Pair combinations of words fold the least amount among all distinguished phraseology units, namely 11 turns, id est $11 \%$ of selection. Idioms (Idiome) form on the whole in German phraseology the most group of stable connections and are characterized by unreplacement, vividness, rethinking. In idioms the sum of components' meaning does not correspond to the general meaning of expression: bis auf den letzten Heller - do останньої копійки, ein guter [hubscher, schoner] Batzen Geld - великий куш; der letzte Dreier - остання копійка. Among all investigated idioms 34 phraseological units are distinguished, id est $33 \%$ of selection.

The winged words are the special type of stable word-combinations in German. Aphorisms, expressions, quotations, sentences, expressions of writers, scientists, politicians, artists belong to them. Authorship of separate expressions in course of time is lost, but the winged words continue to exist in a language.

The winged expressions among the investigated texts fold small part, will point illustrative material: Er liegt auf seinem Geld wie der Hund auf deт Неи - скупому гроші, що собаиі сіно: й сам не гам й іншим не дам; Geld kann man wiedergewinnen - nicht jedoch die Zeit. - Гроші можна відновити - але не час; wo Geld redet, mufi Verstand schweigen. Де говорять гроші, розум мовчить; fur bare Muпzе nehmen - приймати за чисту монету; mit gleicher Munze heimzahlen [zahlen] - платити тією ж монетою; der eine ist einen Dreier wert, der and(e)re drei Pfennige - один одного варті (overall 28 winged expressions, id est $27 \%$ of all selection).

Proverbs are generated by verbal folk work or adopted from certain literary sources, losing connection with these sources. In any case they summarize the experience of people, shown out of their public practice. Although a basic sphere of proverbs functioning is a domestic-colloquial language, they are used also in style of fiction and in style of publicism: Zeit ist Geld - час - uуe гpoui; viel Geld, viel Freunde - багато грошейбагато друзів; Geld stinkt nicht - гроші не nахнуть; keinen [nicht einen] Pfennig wert sein - й ламаного мідного не комтувати; viel Geld, Wenig Verstand - Багато грошей, мало розуму; Besser heut' ein Groschen als 
morgen ein Gulden - Краще синиця в руках, ніж журавель в небі. In our selection proverbs make 30 phraseology units, id est $29 \%$ of selection.

Thus, we analysed phraseology units with a MONEY component in English and German language, taking into account a structure. It is educed that among English phraseology units with a MONEY component most group of phraseological units is formed with the model of word-combination and verbal, the least group is represented with adverb permanent connections; in German we educed plenty of phraseological units with MONEY component, that refer to the proverbs.

\section{Semantics of phraseology units with a component for the notation of money in economic texts in English and German languages}

Analysis of semantics of phraseology units, that develop the concept «MONEY», namely: phraseology units with a keyword (lexical component) money, phraseological units with the name of monetary items or their face value in the lexico-semantic structure, and also phraseological units where sema «money» is presented implicitly, allowed to find out, that a numerous and semantically various class in modern English is presented by phraseological units with the component-name MONEY.

The analysis of the economic articles gave possibility to carry out thematic classification of phraseological units with the componentname MONEY (money, penny, cent, dollar, pound, cash), within the framework of that the groups of phraseological units are distinguished with sema composition of the meaning. Semantic classification of linguist A. M. Chepasova was put in basis of thematic classification. In obedience to this classification all phraseology units are distributed into seven semantic and grammatic classes: procedural phraseology units, qualitative-adverbial, subject, attributive (or attributively-predicative), grammatical, modal and quantitative phraseology units [8, p. 21]. In our research phraseology units with the component-name MONEY were diffused into six semantic groups, in particular:

1) phraseological units on denotation of riches and profit, id est procedural phraseological units with the following meaning: to make money (make money hand over fist - заробляти багато грошей за короткий час; bring an amount of monеy in - заробляти, приваблювати гроші; money doesn't grow on treеs - грошей на дорозі не назбираєш); prosper 
(coin/mint monеу - швидко багатіти, наживатися; there is money in itна изьому можна заробити; топеу begets (breeds, draws, makes) moneyгроші йдуть до грошей;); to have money/much money (be in the money (in pocket, in cash) - nрu грошах; one is rolling in money; have money to burn; be flush with money; be made of money; wallow in money; sink of (with) топеу - грошей кури не клюють); to use money (it takes money to make топеу - щоб заробити гроші потрібно спочатку вкласти їх в якусь справу); to save money (money likes to be counted - гроші люблять рахунок; save топеу ир (for something) - економити гроші для того, щьоб щзось купити; a penny saved is a penny earned - економія грошей шляхом їх збереження - це також спосіб заробляння грошей шляхом nраці); easy money (money for jam; money for old rope - громі, отримані задарма; found топеу - гроші, які потрапили до когось настільки легко, щзо можна сказати, щуо хтось знайшов їх випадково; соте into (some) money and come into a (small) fortune; pennies from heaven несподівано отримати гроші, особливо иляхом успадкування); to be successful (have a good run for your топеу - мати великий період успіху та насолоди). Overall 51 phraseological unit that folds $31 \%$ of selection;

2) phraseological units on denotation of wastefulness and charges with the following meaning: to spend money thoughtlessly (make the money fly; throw money down the drain; spent money like water - cunaти грішми; mоnеу is по оbject - сума не має значення; in for a penny, in for a poundза будь-яку иіну); money spent for free (someone's money went west витрачені гроші пропали марно; be bad топеу - бути невигідним); to spend money quickly (lose/spend money hand over fist - втрачати / витрачати великі гроші за короткий час); гроші, витрачені недарма (money spent on the brain is never spent in vain - громі, витрачені на освіту ніколи не пропадуть; get your топеу's worth - виправдати свої витрати; be good mопеу - бути вигідним); to play for money (play for топеу-грати на гроші; put топеу оn something - ризикувати грошима за результати на перегонах чи змаганні; bиу топеу - робити найвищу ставку на фаворита (на перегонах). Overall 36 phraseological units, that folds $22 \%$ of selection;

3 ) a thematic group on denotation of feelings and looks of man embraces phraseological units with the meaning: confidence (the smart money is on something - коли ті, щуо найкраще проінформовані думають, щчо якась 
подія може трапитися; see the colour of someone's money - мати доказ, щуо хтось може заплатити; be dollars to doughnuts that - бути впевненим); disagreement (nо топеу would buy it - ні за які гроші); незадоволення / страждання (get/take/demand etc. your pound of fleshотримати всі гроші, які хтось вам завинив, навіть, якщяо иче змушує їх страждати, а вам вони не потрібні; fork some money out (for something) платити за щось, можливо неохоче); to have an idea/sense (be right on the топеу -мати правильну думку, або робити чи говорити правильні peчi; put in one's two cents (worth) - додати власний коментарій, думку до дискусї; no more than nine pence in the shilling; not the full shilling не мати сенсу ні на грам). Overall 13 phraseological units, that folds $8 \%$ of selection;

4) in thematic group on denotation of relation of man to money are, in particular, phraseological units with such meaning: positive (money has nо smell - гроші не пахнуть; топеу makes the man - гроші роблять людину; money makes the world go round - гроші змушують світ вертітися); negative (money often unmakes the men who make it-zpoui часто гублять тих, хто їх наживає; a friend at court is better than a penпy in purse - впливовий друг дорожчий за громі; не май 100 рублів, а май 100 друзів; lend your топеу and lose your friend - якщо хочеш втратити друга, то позич йому гроші). Overall 28 phraseological units, that folds $17 \%$ of selection;

5 ) the thematic group on denotation of poverty and lack of money is presented, in particular, by procedural phraseological units with such semantics: poverty (not have a penny to bless yourself with - бymu повністю збіднілим); lack of money ((be short of money (cash; be out of cash; hard up) - не при грошах; not made of money; pressed for money (for cash); pushed for cash (for monеy) - (у когось) мало грошей; live on an amount of топеу - жити, виживати на певну суму грошей). Overall 20 phraseological units, that folds $12 \%$ of selection;

6) in thematic group of phraseological units on denotation of currency and bank transactions we have fixed subject phraseological units with the following meaning: paper money (folding monеy - паперові банкноти; soft monеy - nаперові гроші, банкноти); metallic money (hard money металеві гроші, монети; taken топеу - грошові знаки, розмінна монета; cold hard cash-готівка, монети, або банкноти); cash (ready 
money; money in hand; spending monеy - готівка); fake money (funny топеу - фальшиві (нечесно зароблені) громі; laundered топеу-відмиті гроші; black mопеу - незаконно зароблені гроші, які не пред 'явлені для оподаткування); inflation/devaluation (a run on the dollar/pound - коли багато людей продає долари $і$ їх иінність падає; топороly mопеу гроші, які мають малу иінність, або взагалі ї̈ не мають, тобто не катуються); personal funds (seed топеу-гроші, які використовуються, щзоб почати бізнес чи іншу справу (початковий капітал); crediting (caution топеу - грочова застава); operations with physical and legal people (топеу order - грошовий переказ; smart топеу - компенсація). Overall 16 phraseological units, that folds $10 \%$ of selection.

As a result of undertaken study it is educed that in the given phraseothematic groups the mostly presented are phraseological units on denotation of riches and profit, that laid down $31 \%$ of selection, and the least represented are phraseological units on denotation of feelings and looks of man $-8 \%$. Other components present the following parts: phraseological units on denotation of wastefulness and charges $-22 \%$, phraseological units on denotation of relation of man to money $-17 \%$, phraseological units on denotation of poverty and lack of money $-12 \%$, phraseological units on denotation of currency and bank transactions are $10 \%$ of selection.

The percentage ratio of semantic groups of English phraseological units with MONEY component in the economic sphere is represented on Figure 1.

In relation to semantic classification of German phraseological units, then in our research German phraseology units with the component-name MONEY (Geld, Mark, Euro, Cent) were divided according to the same phraseothematic groups as English phraseology units, in particular:

1) phraseological units on denotation of riches and profit. The group of phraseological units on denotation of riches and profit underlines positive attitude of Germans toward a thrift and their economy. These treats are indeed inherent to German nation and very valued in Germany, that is why it is no wonder that they also found the reflection in phraseology. The amount of money, that is earned by a man, definitely determines his position in society. The property state plays not the last role in the life of Germans, that is why plenty of expressions on this account for certain time passed to the digit of permanent and mean «have (to earn/ to gather) great/certain/significant sum of money»: aber Pfennige haben; eine (die) schnelle Mark verdienen; 


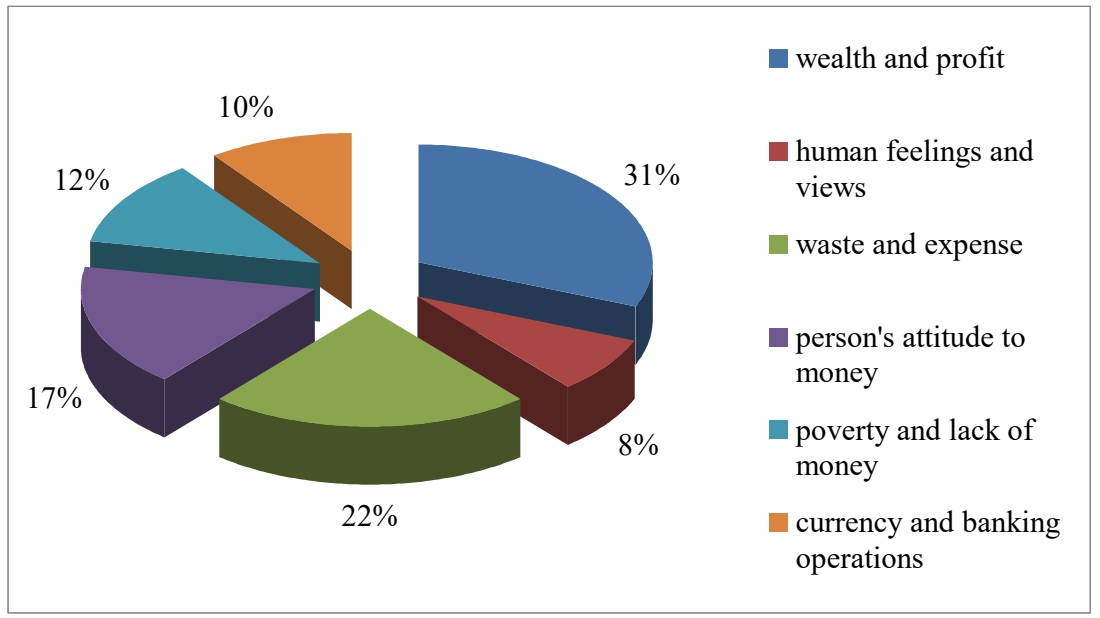

\section{Figure 1. The percentage ratio of semantic groups of English phraseologisms with MONEY component in the economic sphere}

zu Geld kommen; ersticken im Geld; schwimmen im Geld; bei Geld(e) sein; Geld einheimsen [zusammenraffen]; viel Geld bei jmdm. Einkommen; bei Groschen sein; seine paar Groschen zusammenhalten; einen hubschen [schonen] Groschen verdienen. Three of them are synonyms: Geld wie Heu haben; wuhlen im Geld; Geld wie Dreck haben - грошей кури не клюють. Overall 41 phraseological unit that folds $40 \%$ of selection;

2 ) the determined amount of stable word-combinations dedicated to the wastefulness, that is presented in the group of phraseological units on denotation of wastefulness and charges: Geld verpulvern-розбазарювати гроші; das Geld auf die Strafie werfen- швирятися грошима; das Geld (mit vollen, mit beiden Handen) zum Fenster hinauswerfen - кидати гроші на вimep; mit dem Geld(e) um sich werfen [schmeifien] - copити грошима; das Geld auf den Kopf hauen - сорити грошима. It specifies that Germans reprobate squandering and do not like to spend money senselessly. Overall 16 phraseological units, that folds $15 \%$ of selection;

3 ) and on the other hand they also without a positive behave to the avidity, that is the next group of phraseological units, that demonstrates on denotation of feelings and looks of man, in fact such phraseological units, 
as: sehr auf die Groschen sein - бути жадібним; am Geld(e) hangen, dem Geld(e) gut sein - бути жадібним до грошей; Er liegt auf seinem Geld wie der Hund auf dem Неи - Скупому громі, що собаці сіно: й сам не гам й іншим не дам; Pfennigfuchser - скнара, also have the negative colouring. Overall 13 phraseological units, that folds $13 \%$ of selection;

4) phraseological units on denotation of relation of man to money become in case at determination of Germans' treats and their attitude toward certain signs. Germans understand that a capital must be earned and money on the road do not welter: Das Geld liegt nicht auf Strafie. It says about serious attitude toward work. Some phraseology units specify on that they give to money a large value: Das liebe Geldkann alles - Гроші можуть все; Wo Geld redet, da gilt andere Rede nicht-Гроші всі двері відкривають; Geld regiert die Welt - Гроші правлять світом. Навіть дружба залежить від наявності готівки: Viel Geld, viel Freunde - Багато громей - багато друзів. It may give the impression, according to these examples, that for the habitants of Germany money have a greater value, than moral qualities. But it is not so. They consider, that money do not make people happy: Geld macht nicht glucklich, а любов та мужність має для них значно більше значення: Geld macht nicht glucklich; Geld verlorennichts verloren. Mut verloren - alles verloren. Appropriation of stranger money is perceived by Germans with neglect: Geld aus jmdm. ziehen витягати з когось гроші; aus [bei] Geld herausschlage - наживати гроші на чомусь; Geld los sein - позбавлятися грошей; um sein Geld bringen - позбавити грошей. Even when it is going about borrowing money, it causes negative associations for Germans. Take, for example, phraseological unit «Geld pumpen (bei, von)». A word «pumpen» has a direct initial meaning to «pump out anything», and later it got connotation to «occupy something», that, by the way, is colloquial. Thus, it is possible to draw conclusion, that this stable word-combination has a negative connotation. Overall 9 phraseological units, that folds $9 \%$ of selection;

5) absence of money is represented in the following phraseology units on denotation of poverty and lack of money: weder Geld noch Gut habenне мати ані копійки; knарр mit Geld sein - мати мізерні кошти; die lumpigen paаr Mark - жалюгідні гроші або надмірні витрати: letzten paar Groschen ausgeben - витратити останні гроші; schweres Geld kosten - дорого обходитись; etw. ins Geld laufen[gehen] - влітати в 
копійочку; etw. ins Geld reifien - бити по кишені) також не схвалюється. Overall 12 phraseological units, that folds $12 \%$ of selection;

6) group of phraseological units on denotation of currency and bank transactions contains such phraseology unity: Geld auf der Bank habenзберігати гроші в банку; von seinem Geld(e) leben - жити на відсотки 3 капіталy. It says that to keep a capital in a bank is for Germans quite usual business, and that is why the word-combinations sanctified to this theme passed to the digit of permanent. The theme of taxes also found a reflection in phraseological units: Geld kassieren [einkassieren] - збирати гроші, податки. Germans, as nobody other, know this theme, whereas, as it is a well-known fact, that Germany is one of countries in the world with the greatest level of taxes, that is why they are forced to save (sehr aufs Geld sehen, jede Mark umdrehen, den Pfennig ansehen - бути дуже економним), and able to obtain a material benefit (in klingende Munze umsetzen). Phraseology can also specify on the cognation of languages, so, for example, phraseology unity «Geld anlegen» (to input money) is not especially German, and originates from English phraseological unit «make money». Overall 12 phraseological units, that folds $11 \%$ of selection (see Figure 2).

The research results show that in German also mostly presented group of phraseological units on denotation of riches and profit that folds $40 \%$ of selection, and the least are phraseological units on denotation of relation of man to money $-9 \%$.

Also on Fig. 3 and 4 illustrative material in relation to frequency of the use of English and German phraseological units with a certain MONEY component is pointed.

It is validified that mostly in investigated English economic texts phraseological units are used with the MONEY component money (51\%), and in German also with the MONEY component Geld $(49 \%)$, so it is possible to draw conclusion, that in both languages the most frequent are phraseological units exactly with a component «money». Rarer of all in English economic texts there are phraseology units with the MONEY component pound (5\%), and in German - with the component Cent (12\%).

Thus, research of different classifications of phraseology composition of language helps to find out nature of phraseology units, and also their place and features of functioning in the language system. On the whole from 


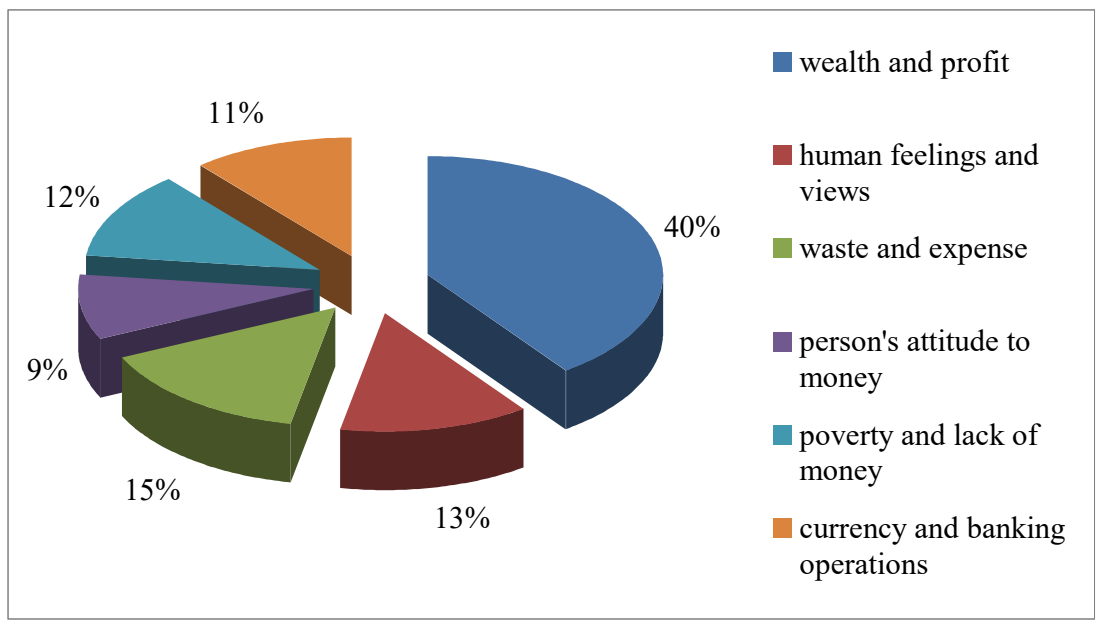

Figure 2. The percentage ratio of semantic groups of German phraseological units with MONEY component in the economic sphere

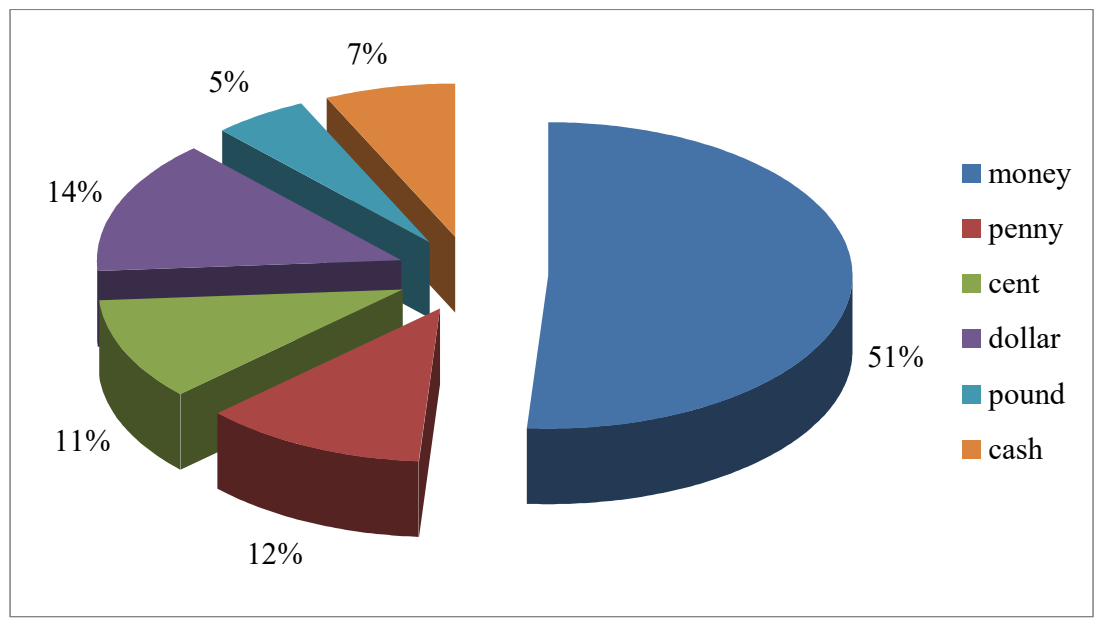

Figure 3. Frequency of English phraseologisms with MONEY component in economic texts usage 


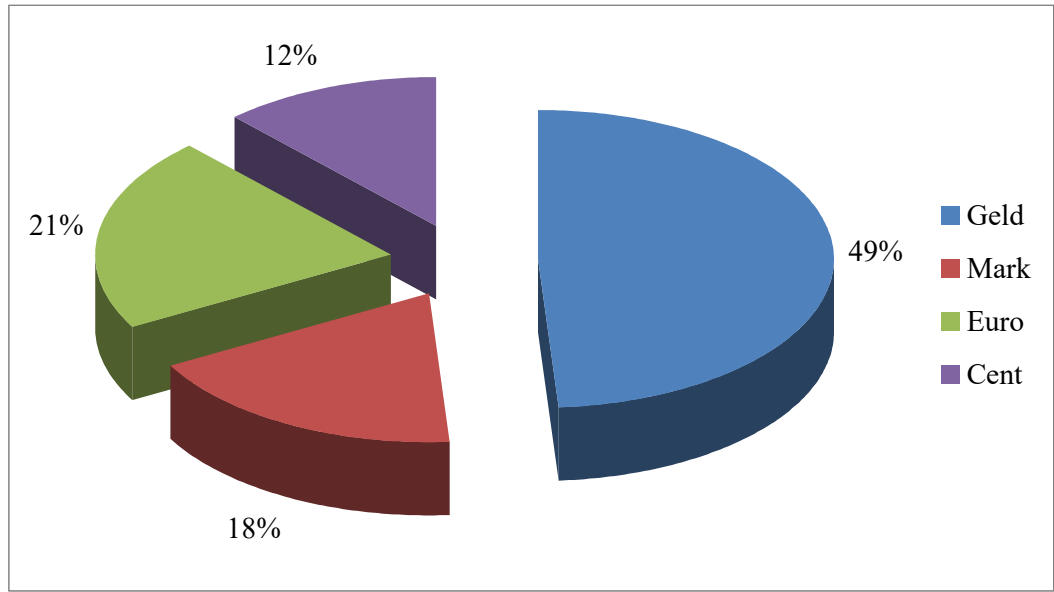

Figure 4. Frequency of German phraseologisms with MONEY component in economic texts usage

undertaken study we came to the conclusion, that from the semantic point of view English and German phraseology units with a MONEY component are alike enough in semantic classification, as the most in English and German economic texts is folded by phraseology groups on denotation of riches and profit (accordingly 31\% and 39\%); on the other hand, in English the least are phraseological units on denotation of feelings and looks of man $(8 \%)$, and in German - phraseological units on denotation of relation of man to money $(9 \%)$.

\section{Specific of English and German phraseology units with a component on denotation of MONEY into Ukrainian language translation}

Such scientists, as L. F. Dmytriyeva, S. Y. Kuntsevych, Y. A. Martynkevych and N. F. Smirnov distinguished four basic methods of phraseological units translation [3, p. 36-39].

For research of features of phraseology units with a component on denotation of MONEY translation we analysed 164 English phraseological units, that were investigated and described the main ways of their translation. 
The results of our research show that in the process of translating of phraseology units with a component on denotation of MONEY the method of translation by a phraseology equivalent is mostly used. At application of such accordances all meaning of the translated unit is kept in a complex. In such case the full meanig on all parameters with phraseology unit of textoriginal coincides, for example: things are obedient to money - вci peri nідвладні грошам; топеу makes the mare gо - за гроші і кобила пращює; one is rolling in money, to be rolling in the money; have money to burn; be flush with money; be made of money, wallow in money; to wallow in wealth; sink of (with) mопеу - грошей кури не клюють.In our research 85 units, id est $52 \%$ from an investigated were translated by selection of equivalent.

In such case, when a phraseology equivalent is absent in the language of translation, it is possible to apply the method of analogue selection to the phraseology unit and it is necessary to pick up phraseological unit with the same figurative sense, that is based on other character, for example: pin топеу - кишенькові гроші; топеу пеvеr comes out of season - гроші ніколи не виходять з моди. In our research by this method 34 units were translated, id est $21 \%$ from an investigated selection.

With the aim of the essence of phraseology unit opening, that does not have equivalent and analogue in the language of translation, and that is not subject to literal translation, it costs to resort a translator to descriptive translation. For example: money spent on the brain is never spent in vainгроші, витрачені для розвитку розуму, ніколи не бувають витрачені даремно; spend money like it is going out of fashion - витрачати гроші так, ніби вони не мають ніякого значення; smart топеу - вигідно інвестовані кошти, особливо на підставі неофіційної інформації, розумне капіталовкладення. In our research such method was got in 27 units, that laid down $16 \%$.

Literal translation or calquing of phraseology units can be used in that case, when at its application have expression, the vividness of that is perceived easily by a reader and that does not give the impression of unnaturalness, and also meets the generally accepted standards of Ukrainian language [3, p. 64]. For example: money likes to be counted-гроші люблять рахунок; топеу is a good servant, but a bad master - гроші-хороший слуга, але поганий господар; топеу is the root of all evil - громі корінь всього зла. Calques-accordances have certain advantages and are 
used often enough in the process of translation. They, firstly, allow to save the vivid line-up of original that is considerably important in translation of artistic works. Secondly, it does possible to avoid difficulties that can appear then, when in the text-original the image is «played» for creation of the unfolded metaphor [5, p. 174]. In our research by this method 18 units were translated, that laid down $11 \%$ from a general amount.

The carried analysis of the main features of English phraseology units with a MONEY component into the Ukrainian language translation did possible the reflection of research results by means of the following diagram (see Figure 5).

Thus, as our research testifies, in English there is a lot of phraseology turns with a component MONEY. They demonstrate both positive and negative attitude toward money in both languages. In order to pass the essence of phraseology expression maximally exactly, the use of only literal translation is not enough. A professional translator must successfully pick up an equivalent that will correspond the original on maintenance and by vividness.

Translation of German phraseological units is based upon the formal interlingual accordances conditioned by community of the concept systems for the representatives of different languages. Considerable part of such accordances was folded historically in the process of contacts between people.

Linguists S. I. Vlahov and S. P. Florin offered two methods of German phraseological units translation: phraseology (use of equivalent and analogue) and unphraseology (calquing and descriptive) translations [2, p. 179].

Phraseology translation is the use in the text of translation stable units of different degree of likeness. Sometimes for translation of phraseological units it is not necessary to create new stable expressions, as in a language into which phraseological unit is translated, already there are exact or alike phraseology units. Phraseology translation includes absolute phraseology and relative phraseology equivalents.

1. Absolute phraseology equivalents, that coincide in lexical and phraseology meaning, grammatical structure, lexical composition, stylistic colouring, and also according to the use in a language. Some researchers, in particular L. S. Barhudarov, mark that cases of complete coincidence of lexical units of different languages in full volume of their reference meanings relatively rarely happen in a language $[1, \mathrm{p} .75]$. 


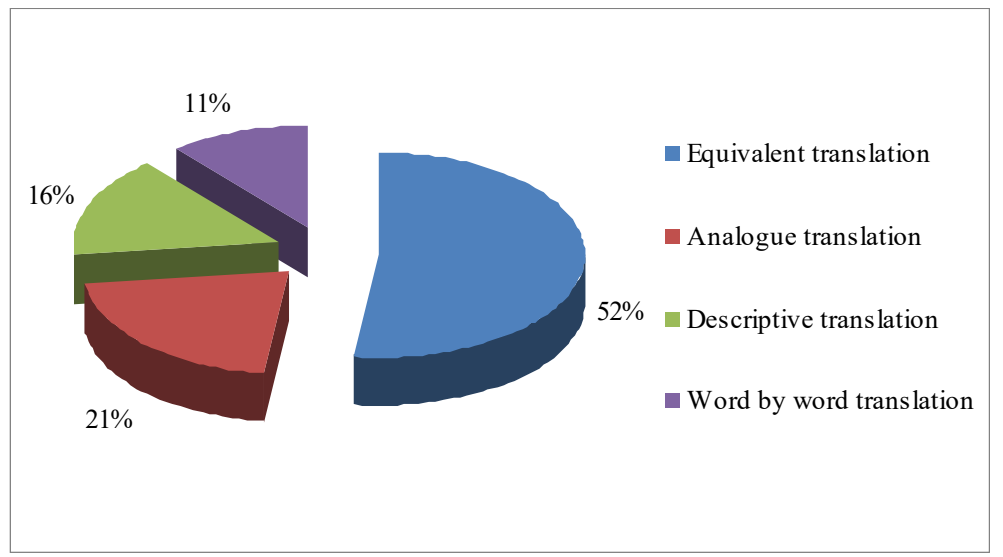

\section{Figure 5. The frequency of translating methods of English phraseologisms with MONEY component usage}

By absolute phraseology equivalents are mainly translated:

a) phraseology expressions (proverbs, sayings, international phraseological units and others like that): auf dem großen Fuß leben жсити на широку ногу; bei Groschen sein - бути при грошах; keinen [nicht einen] Pfennig wert sein - й ламаного мідного не коштувати;

b) some pair word-combinations: auf Heller und Pfennig Rechnung ablegen - звітувати за кожну копійку; mit auf Heller und Pfennig abrechnеn - сповна розрахуватися;

c) considerable part of comparative phraseology units: Geld wie Dreck haben-грошей кури не клюють; Er liegt auf seinem Geld wie der Hund auf deт Неи - скупому гроші, що собачі сіно: й сам не гам й іншим не дам;

d) some verbal word-combinations: weder Geld noch Gut haben - не мати ані копійки; letzten paаr Groschen ausgeben-витратити останні гроші; schweres Geld kosten - дорого обходитись.

In our research 49 units, id est $48 \%$ from an investigated selection were translated by equivalent selection.

2) Partial phraseology equivalents, when phraseology units in the compared languages have lexical, grammatical and lexico-grammatical differences at an identical meaning and the same stylistic painting. Among partial phraseology equivalents distinguish: 
a) Ukrainian phraseology equivalents of German phraseology units, that coincide by meaning, stylistic colouring, close to their internal form, but have certain lexical differences: etw. ins Geld reifien - бити по кишені (також не схвалюється); das ist nicht fur Geld feil [zu haben] - ие не для продажу;

b) Ukrainian phraseology equivalents of German phraseology units, that coincide by meaning, by internal form, stylistic colouring, but have certain grammatical divergences: das ist allerhand fur 'n Groschen! - Чu не багато захотів mit dem Geld(e) um sich werfen [schmeifien]; das Geld auf den Kopf hauen - сорити грошима.

c) Ukrainian phraseology equivalents of German phraseology units, that coincide by meaning, stylistic colouring, but have certain lexical divergence in the plan of internal form: von seinem Geld(e) leben - жити на відсотки з капіталу; dem Geld(e) gut sein - бути жадібним до грошей.

Most German proverbs and sayings are translated by means of partial phraseology equivalents, that keep the national colour of language. It costs to mark that some researchers, in particular V. I. Karaban and S. I. Vlahov, name partial phraseology equivalents as «relative phraseology equivalents». S. I. Vlahov under a term «partial phraseology equivalents» understands such equivalents, that will be realized in the language of translation not in full meaning of initial phraseological unit [2, p. 181]. Such phenomenon arises up, when phraseological unit in original language has a few meanings.

3) Contextual phraseology equivalents, that are widely used in the process of sayings, proverbs, phraseology units of intonement translation and others like that. Translation by means of contextual phraseology equivalents envisages wedging of words-components for more adequate transmission of German phraseological unit's meaning. For example: das ist keinen Taler wert - ие не варте й ламаного грома (щербатої копійки); um sein Geld bringen - позбавити грошей.

In our work by this method 24 units were translated, id est $23 \%$ from an investigated selection.

2. Unphraseology translation of phraseology units from German into Ukrainian. This type of translation is succeeded when phraseology equivalent in Ukrainian language is absent. In such case the following types of translation are distinguished: 
1) Descriptive translation, when the meaning of German phraseology unit is passed to the variable word-combinations without the specific formal genre-stylistic features of phraseology units. Description is used in case, when the absolute or partial equivalent of German phraseology unit is absent in Ukrainian, and verbal translation of this phraseology unit is impossible. Such translation envisages the transmission of general maintenance of the German permanent word-combination with an ordinary word or wordcombination of unphraseology character. Vivid German phraseology unit loses the vividness, so only its common meaning is passed. In such cases phraseology units of terminological character, that can not be translated differently, mostly translated in such way: das liebe Geld kann alles - zpowi можуть все; sehr aufs Geld sehen, jede Mark umdrehen, den Pfennig ansehen - бути дуже економним; Wo Geld redet, da gilt andere Rede nicht-гроші всі двері відчиняють.

In our research such method was got in 11 units, that laid down $12 \%$.

2) Literal translation, or calquing, that envisages a word for word transmission of German phraseology unit into Ukrainian language. This method is used in cases, when expression includes realities, that are characteristic for German language or when non-equivalent phraseology units are translated, if they can not be translated differently: Geld aus jmdm. ziehen - витягати з когось гроші; Geld anlegen - вкладати гроші; sein Geld im Strumpf aufheben [aufbewahren] - зберігати громі в панчосі.

In our work by this method 19 units were translated, that laid down $17 \%$ from a general amount.

Carried analysis of features of German phraseology units with a MONEY component into the Ukrainian language translation did possible the reflection of research results by means of the following diagram (see Figure 6).

On the whole from undertaken study we came to the conclusion, that translation of phraseology units with a MONEY component is alike enough both in English and German languages. Greater part of our selection is folded by phraseology equivalent translation that presents $52 \%$ in English and $48 \%$ in German. At the same time the least percent of our selection of phraseology units with a MONEY component translation in English presents literal translation, that constitute $11 \%$, whereas in German the least percent of our selection has descriptive translation, namely $12 \%$. 


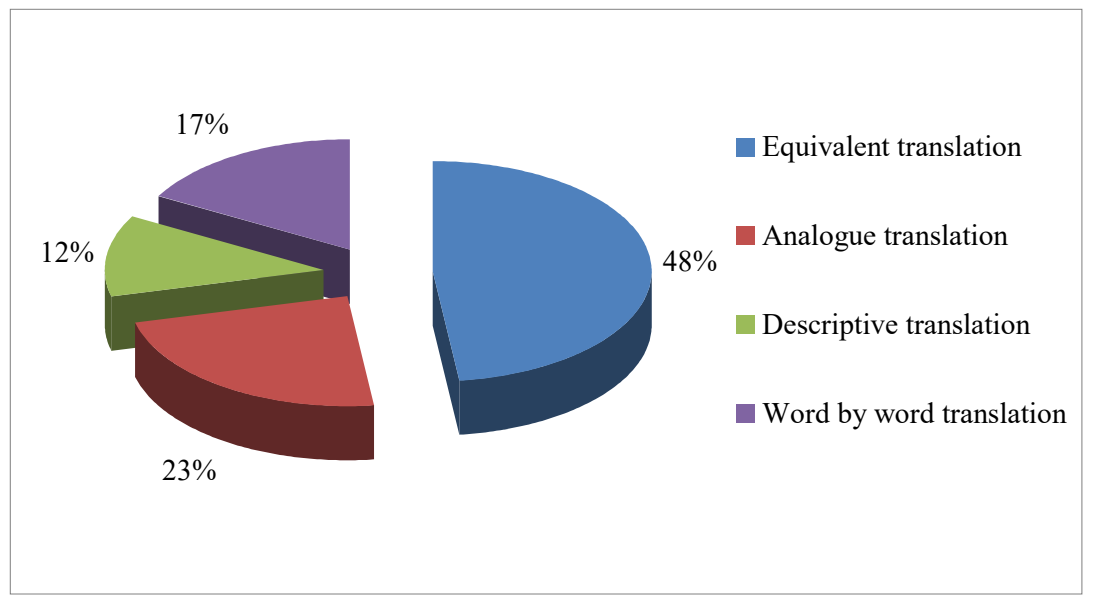

\section{Figure 6. The frequency of translating methods of German phraseologisms with MONEY component usage}

\section{Conclusions}

As a result of undertaken study it is exposed, that phraseological units with a component «MONEY « have semantically-cultural features. They are a national and cultural information generator and exactly in phraseology unities it acquires a bright and direct display. Phraseology composition incarnates cultural concepts, as mentality of people is represented in it. It is also possible to set leaning on these phraseological units, what values are present in one or other culture.

It was set as a result of research, that phraseology units in a structural relation are various enough, however in English mostly verbal phraseological units are distinguished. Among German phraseological units with a MONEY component the most is distinguished among the German sayings. According to semantic classification English and German phraseology units with a MONEY component were divided into such groups: on denotation of riches and profit, wastefulness and charges, feelings and looks of man, relation of man to money, poverty and lack of money and on denotation of currency and bank transactions. Undertaken study educed that both in English and German language most phraseology units with a MONEY component on denotation of riches and profit (31\% in English and 40\% - 
in German) are used, the least part is presented by phraseology units with a money component on denotation of feelings and looks of man $-8 \%$ in English, and in German on denotation of relation of man to money $-9 \%$.

Basic methods of phraseological units translation that are used by translators for the achievement of maximal adequacy of translation are distinguished. Among the methods of English phraseological units translation with a MONEY component the following one are distinguished: selection of equivalent, analogue, by the method of literal and descriptive translation whereas German phraseology units with a MONEY component are translated by phraseology and unphraseology methods; to phraseology the method of selection of eauivalent or analogue is taken, to unphraseology correspond calquing and descriptive translation.

It is well-proved that knowledge of features of phraseological units and methods of their translation indisputably promotes efficiency of translation and gives an opportunity to deepen knowledge about a culture and traditions of people the language of that is studied as well as to enrich an own world outlook.

\section{References:}

1. Barhudarov, L. S. (2005) Language and translation. M.: Higher school.

2. Vlahov, S., Florin, S. (2009) Untranslatable in translation. M.: Valent.

3. Dmitriieva, L. F., Kuntsevych, S. Y., Martynkevych, Y. A. and Smirnova, N. F. (2005) English for students. Course of translation. Rostov-on-Don.

4. Iskoz, A. M. and Lenkova, A. F. (1999) Jlexicology of German language. St. Petersburg.

5. Korunets, I. V. (2003) Comparative typology of English and Ukrainian languages: tutorial. Vinnytsia: Nova knyha.

6. Uzhchenko, V. D., Uzhchenko D. V. (2005) Phraseology of modern Ukrainian language: tutorial for students of phylology departments of higher educational establishments. Luhansk: Alma-mater.

7. Uzhcheno, T. H. (1995) The meaning of phraseology unit. The origin of the structure of phraseology // Didactic materil on Ukrainian language. Vocabulary and phraseology. Kyiv: Lybid.

8. Chepasova, A. M. (2006) Semantics and grammatical classes of Russian phraseological units: [tutorial]. Cheliabinsk: State pedagogical university publishing house. 